The Pragmatic Case for Legal Tolerance

Peer-reviewed author version

SMET, Stijn (2019) The Pragmatic Case for Legal Tolerance. In: Oxford Journal of Legal Studies, 39(2), p. 344-373.

DOI: $10.1093 /$ ojls/gqz007

Handle: http://hdl.handle.net/1942/28435 


\title{
The Pragmatic Case for Legal Tolerance
}

\author{
Stijn Smet
}

Tolerance has been studied and critiqued extensively in moral and political philosophy. By contrast, we know relatively little about the salience of tolerance to law. In this article, I aim to fill that gap in our knowledge by making a conceptual case for legal tolerance in constitutional democracies. More specifically, I aim to make a pragmatic case for legal tolerance. The article's core arguments are that (a) lawmakers often engage in legal tolerance of contested beliefs, opinions and practices, and (b) they tend to do so for pragmatic reasons. In building the pragmatic case for legal tolerance, I discuss legal responses in a wide array of jurisdictions and to a broad range of contested moral issues. I also unpack the implications of legal tolerance by analyzing its (in)stability and its relationship to state communicative power. I conclude the article by indicating some potential limits of pragmatic legal tolerance.

Keywords: tolerance, pragmatism, reasonable disagreement, contested moral issues.

\footnotetext{
${ }^{*}$ Assistant Professor of Constitutional Law at Hasselt University and Senior Research Associate to the Laureate Program in Comparative Constitutional Law at Melbourne Law School (stijn.smet@uhasselt.be and stijn_smet@msn.com). I am indebted to Adrienne Stone, Farrah Ahmed, Erika Arban, Gary Hansell, Tarun Khaitan and participants in conferences at Melbourne Law School and the University of Auckland Law School for probing questions, useful suggestions and invaluable feedback on earlier drafts. I am also grateful to both referees at $O J L S$ for their rigorous reviews, containing both constructive criticism and helpful suggestions. The research presented in this article was funded by the Australian Government through the Australian Research Council Laureate Program 'Balancing Diversity and Social Cohesion in Democratic Constitutions' (project ID: FL160100136).
} 


\section{Introduction}

The notion 'tolerance' is routinely invoked in political and philosophical debates about how we should respond to the social fact of religious, cultural and other forms of diversity. Yet tolerance - the conscious decision not to interfere with beliefs, opinions and practices of which one disapproves - is hardly a noble virtue. Instead, it may well be an 'impossible virtue'. ${ }^{1}$ Unlike attitudes of indifference or acceptance, tolerance is profoundly schizophrenic. ${ }^{2}$ The tolerant disapprove of certain beliefs, practices or opinions, but (reluctantly) permit them regardless. ${ }^{3}$ Nevertheless, or perhaps because of this ambiguous combination of disapproval and permission, tolerance remains a core commitment of liberalism. Tolerance is considered central to ensuring peaceful co-existence in societies marked by religious, cultural and ethnic diversity. ${ }^{4}$ In an ideal world, perhaps, everyone would treat others with respect. But in our real world, tolerance may be the best we can hope for. ${ }^{5}$ Tolerance, in other words, is what works in practice.

But whereas the value or virtue of tolerance has been studied and critiqued extensively in moral and political philosophy, we know comparatively little about the salience of tolerance to $l a w .{ }^{6}$ In this article, I begin to fill that gap in our knowledge by making a conceptual case for legal tolerance in constitutional democracies. More specifically, I aim to make a pragmatic case for legal tolerance. In doing so, I largely eschew normative arguments. That is, I do not argue that lawmakers ought to (sometimes) opt for legal tolerance instead of

\footnotetext{
${ }^{1}$ Bernard Williams, 'Toleration: An Impossible Virtue?' in David Heyd (ed), Toleration: An Elusive Virtue (Princeton University Press 1998) 18-27.

2 Tolerance's schizophrenia generates a few troubling paradoxes. One of these is the paradox of the tolerant racist. This paradox highlights the perverse potential of tolerance. Ironically, the more deeply a racist disapproves of persons with a different ethnicity, the more tolerant she/he becomes by forbearing from persecuting them. See Ian Carter, 'Are Toleration and Respect Compatible?' (2013) 30 J of Applied Phil 195, 203.

3 John Horton, 'Why the Traditional Conception of Toleration Still Matters' (2011) 14 Crit Rev Intl Soc and Pol Phil 289, 290.

${ }^{4}$ John Rawls, Political Liberalism (Expanded edn, Columbia University Press 2005) 157, 486 and 488.

${ }^{5}$ Horton (n 3) 292, 299 and 303.

${ }^{6}$ But see Carl Stychin, 'Faith in the Future: Sexuality, Religion and the Public Sphere' (2009) 29 OJLS 729.
} 
prohibition, indifference or acceptance. Instead, I provide the double descriptive argument that (a) in actual practice, legal actors often engage in legal tolerance of contested beliefs, opinions and practices, and (b) they tend to do so for pragmatic reasons. ${ }^{7}$

Throughout the article, I substantiate both descriptive claims by discussing legal responses, in a wide array of jurisdictions, to a broad range of contested moral issues: prostitution, marijuana consumption, tobacco use, hate speech, blasphemy and conscientious objection to abortion and same-sex marriage. In analysing these practical examples, I aim to show that legal tolerance plays a key role in constitutional democracies. I further argue, in support of the practice, that policies of legal tolerance work best when they are founded on pragmatic reasons. I explain later what I mean exactly by pragmatic reasons. In short, they are a subset of instrumental reasons, to which both sides of a moral controversy can agree without abandoning their fundamental underlying positions. As such, pragmatic reasons supply less contentious - and therefore more stable - grounds on which to support policies of legal tolerance.

I unpack the above claims throughout the article. In doing so, I intend to make an initial case for pragmatic legal tolerance. The case will not be conclusive, since its definitive merit depends on the accuracy of the claim that legal tolerance works best when supported by pragmatic reasons. As will become clear in due course, these pragmatic reasons often rest on contestable assumptions. Therefore, more is needed in the way of empirical evidence than I intend to - or indeed can - supply in this article, before a conclusive case for pragmatic legal tolerance can be made out. Instead, my aim in this article is to lay the conceptual groundwork for a pragmatic case for legal tolerance.

\footnotetext{
${ }^{7}$ I use the term 'legal actors' to refer not only to legislators, but also to judges and prosecutors who engage in legal tolerance. For ease of reference, I sometimes use the term 'lawmakers' in the text, to refer to the same.
} 
Why this is important is explained immediately below, in section 2, where I present the core of the case for pragmatic legal tolerance. Afterwards, in section 3, I analyse legal responses to a wide range of contested moral issues in an array of constitutional democracies, with a view to substantiating the pragmatic case for legal tolerance. In section 4 , I discuss the most salient implications of pragmatic legal tolerance, to wit its (in)stability and its relationship with state communicative power. I conclude the article by indicating some potential normative and empirical limits of the pragmatic case for legal tolerance.

\section{The Core of the Case for Pragmatic Legal Tolerance}

As is well known, tolerance was key to bringing about (relatively) peaceful religious coexistence in early modern Europe. In societies rife with religious violence, John Locke, Pierre Bayle and Baruch de Spinoza argued for tolerance of religious difference to end religious persecution and wars. ${ }^{8}$ The virtue of tolerance, later expanded to cover other forms of diversity, has remained a hallmark of liberal thought ever since. ${ }^{9}$ But contemporary liberal theory - political liberalism, in particular - leaves little room for state tolerance, ie tolerance practiced by the state towards its citizens. Instead, the liberal state is generally held under a duty of neutrality. The state should not, on political liberalism at least, disapprove of citizens' comprehensive conceptions of the good. ${ }^{10}$ Given that disapproval is inherent to tolerance, this implies that the liberal state ought not to engage in tolerance. ${ }^{11}$ 'With the establishment of

\footnotetext{
${ }^{8}$ Rainer Forst, 'Pierre Bayle's Reflexive Theory of Toleration' in Melissa S Williams and Jeremy Waldron (eds), Toleration and Its Limits (New York University Press 2008) 78-113.; Geoffrey A Gorham, 'Spinoza, Locke, and the Limits of Dutch Toleration' (2011) 27 Macalester Intl 12.

${ }^{9}$ See John Stuart Mill, On Liberty, Utilitarianism, and Other Essays (Mark Philp and Frederick Rosen eds, new edn, OUP 2015); Rawls (n 4).

${ }^{10}$ Rawls (n 4).

${ }^{11}$ John Gray, 'Pluralism and Toleration in Contemporary Political Philosophy' (2000) 48 Pol Stud 323, 323 and 326.
} 
modern liberal democracy', David Heyd argues, 'the idea of toleration [has become] superfluous in its traditional political form'. ${ }^{12}$

Political arguments against state tolerance are complemented by moral arguments that object to the disapproval and power imbalance inherent in tolerance. The moral counterargument is simple: minorities do not wish to be tolerated by the state, given the disapproval and subordination this entails. Instead, they demand something more: acceptance, respect and/or recognition. ${ }^{13}$ Martha Minow, for instance, views liberal tolerance as 'a second-best, a kind of "putting up with" difference that falls short of genuine respect'.14 Martha Nussbaum similarly favours the notion of (equal) respect, rejecting tolerance as 'too grudging and weak' an attitude. ${ }^{15}$ Minow and Nussbaum thus argue for a move beyond tolerance towards respect.

In today's constitutional democracies, it seems, the space for state tolerance has been consumed by the competing spaces of neutrality and respect. The attending 'attitudes' of the state can be described as either indifference, in the space of neutrality, or acceptance, in the space of respect. The neutral state is expected to be indifferent to the substantive content of contested beliefs, practices and opinions. Its policies are to be determined entirely by harm analysis of the impact of these beliefs, practices and opinions, without judging their content. The respectful state, by contrast, is expected to accept citizens' beliefs, practices and opinions,

\footnotetext{
${ }^{12}$ David Heyd, 'Is Toleration a Political Virtue?' in Williams and Waldron (n 8) 175.

${ }^{13}$ Susan Mendus, Toleration and the Limits of Liberalism (Macmillan 1989) 159; Anna E Galeotti, Toleration as Recognition (CUP 2002) 10-11. For discussion, see Leslie Green, 'On Being Tolerated' in Matthew H Kramer (ed), The Legacy of H.L.A. Hart: Legal, Political, and Moral Philosophy (OUP 2008) 277-97.

${ }^{14}$ Martha Minow, 'Tolerance in an Age of Terror' (2006) 16 S Cal Interdiscip LJ 453, 457.

${ }^{15}$ Martha C Nussbaum, Liberty of Conscience: In Defense of America's Tradition of Religious Equality (Basic Books 2010) 24.
} 
including contested ones. The kind of acceptance that attends state respect arguably entails positive regard for citizens' life choices. ${ }^{16}$

On the liberal-philosophical arguments from neutrality and respect, it is not appropriate or acceptable for the state to disapprove of contested beliefs, practices and opinions. Hence the philosophical argument that there is no room for state tolerance in contemporary constitutional democracies. In this article, I want to push back against the dominant philosophical narratives by showing that state tolerance continues to be relevant and prevalent - in actual practice. ${ }^{17}$ Relative inattentiveness to the role of tolerance in law, I suggest, has obscured how tolerance remains a central tool used by liberal states to regulate controversial moral issues. ${ }^{18}$

By taking the tolerance debate out of the realm of philosophy and bringing it into law, I intend to make a pragmatic case for legal tolerance. That case consists of two separate, but interconnected components: a conceptual claim and a descriptive hypothesis with normative undertones. Here, I introduce both components. They are substantiated and tested in the remainder of the article.

The conceptual claim, which is entirely descriptive in nature, is relatively simple: tolerance plays an extensive role in law. Throughout the article, I aim to demonstrate that the law's response to a broad range of contested practices, and in a wide array of countries, meets the analytical structure of tolerance. This analytical structure combines two opposing forces: disapproval and permission. When the law tolerates a given practice, it permits said practice despite disapproval thereof. Consider, for instance, the law on marijuana. In many countries,

\footnotetext{
16 See Brian Leiter, Why Tolerate Religion (Princeton University Press 2012) (in which Leiter argues, convincingly, that the philosophical argument for respect draws on Stephen Darwall's notion of appraisal respect, which is synonymous with high regard or esteem).

${ }^{17}$ See also Horton (n 3); Joseph Raz, 'Autonomy, Toleration, and the Harm Principle' in Susan Mendus (ed), Justifying Toleration: Conceptual and Historical Perspectives (CUP 1988) 155-76.

${ }^{18}$ See also Steven Smith, 'The Restoration of Tolerance' (1990) 78 Cal L Rev 305.
} 
the criminal law (qua 'law on the books') penalizes the sale and possession of marijuana, thereby expressing disapproval. But in some of those countries, such as the Netherlands, the criminal law on marijuana is deliberately left unenforced. The conscious decision not to prosecute the crime entails a de facto permission. In other words, the 'law in action' tolerates the sale and possession of marijuana. This is one example of legal tolerance. I discuss other examples throughout the article.

Whereas the conceptual claim serves to establish the salience of tolerance to law, the second component identifies the pragmatic qualities of legal tolerance. To that end, I propose - and test - the hypothesis that lawmakers tend to adopt policies of legal tolerance for pragmatic reasons, rather than deontological reasons. In substantiating this hypothesis, I move beyond the merely descriptive. I also argue, in more normative terms, that policies of legal tolerance work best when they are supported by pragmatic reasons.

The core argument, here, is that legal tolerance works best in practice if and when it is founded on pragmatic reasoning. By pragmatic reasoning, ${ }^{19} \mathrm{I}$ mean a specific form of instrumental reasoning that sidesteps deontological disagreement on moral issues by appealing to shared practical reasons, to wit reasons related to the consequences of legal regulation that can find support on both sides of a given moral controversy. ${ }^{20}$ Pragmatic reasons are thus a subset of instrumental reasons, on which both sides of a moral controversy

\footnotetext{
${ }^{19}$ One of the central difficulties in the debate on the role of pragmatism in law is the challenge in pin-pointing what pragmatism means, exactly, and where its precise contribution to law lies. See Brian Tamanaha, 'Pragmatism in U.S. Legal Theory: Its Application to Normative Jurisprudence, Sociolegal Studies, and the FactValue Distinction' (1996) 41 Am J Juris 315; Charles Barzun, 'Three Forms of Legal Pragmatism' (2018) 95 Wash U L Rev 1003.

${ }^{20}$ This aligns with legal pragmatism's attentiveness to the factual consequences of legal decision-making, rejecting legal reasoning from abstract principles. See Thomas Grey, 'Holmes and Legal Pragmatism' (1989) 41 Stan L Rev 787; Richard Posner, 'What Has Pragmatism to Offer Law' (1989) 63 S Cal L Rev 1653; Richard Posner, The Problematics of Moral and Legal Theory (Harvard University Press 2002); Tamanaha (n 19) 336. Holmes and Posner incorporated in law the philosophical pragmatism of, among others, William James and John Dewey. See William James, 'Philosophical Conceptions and Practical Results' (1898) 1 University Chronicle 287, 290 and 308; John Dewey, 'What Does Pragmatism Mean by Practical?' (1908) 5 J Phil Psych and Sci Methods 85, 85-86.
} 
can agree without abandoning their fundamental underlying positions. ${ }^{21}$ These fundamental underlying positions generally rest on deontological claims that are linked to competing ideologies. In turn, deontological claims tend to entrench contestants in society in their respective moral viewpoints, which generates protracted and sometimes insoluble disagreement.

Given this context, grounding legal tolerance in one of several competing deontological claims is unlikely to enable stable solutions to moral controversies. Instead, it risks furthering polarisation in society. When lawmakers regulate moral controversies by balancing the deontological arguments that support competing normative viewpoints, they are liable to deepen societal divisions rather than alleviate them. Pragmatic legal tolerance, I wish to argue, provides a useful alternative in that it effectively sidesteps protracted deontological disagreement by supplying less contentious reasons in support of legal policy. ${ }^{22}$ This is so because pragmatic reasons, as defined in this article, are reasons to which both sides of a moral controversy can in principle subscribe, given that they focus on consequences that are of shared concern. In the face of protracted ideological division, pragmatic legal tolerance thus enables more stable - because less contentious - legal responses to moral controversies.

Consider, by way of initial explication, the morally controversial issue of conscientious objection to abortion (other examples are discussed below). When doctors refuse to perform abortions for reasons of religious conscience, lawmakers can respond in a variety of ways. They can insert conscience clauses in abortion legislation, out of respect for the religious conscience of doctors. Or they can prohibit conscientious objections, guided by disapproval of doctors' refusal to perform abortions. But lawmakers can also choose to permit

\footnotetext{
${ }^{21}$ This aligns with the most prominent accounts of legal pragmatism. See Grey (n 20) 788 and 805; Posner, The Problematics of Moral and Legal Theory (n 20) xii and 227; Barzun (n 19) 1031.

${ }^{22}$ Basing legal tolerance on pragmatic grounds renders it less controversial and thus less problematic from the vantage point of political philosophy (particularly political liberalism with its emphasis on neutrality) than might at first appear to be the case.
} 
conscientious objections despite disapproval thereof. The latter response is one of legal tolerance, which can in turn be supported by different kinds of reasons.

A possible deontological reason to tolerate doctors' refusal to perform abortions is deference to their personal autonomy. Yet personal autonomy is at the very heart of divisive controversies over abortion. By explicitly giving more weight to a doctor's right to refuse than a woman's right to choose, lawmakers risk intensifying societal division over abortion rather than alleviating it. What the pragmatic case for legal tolerance suggests, is that lawmakers do well to ground legal tolerance on pragmatic reasons instead. In the abortion case, a central pragmatic reason is to ensure the safety of surgical abortions by not forcing doctors to proceed with an act they feel incapable of performing, and would presumably perform badly if coerced to do so. Crucially, contestants on both sides of the moral controversy can subscribe to the importance of avoiding bad or dangerous surgery, regardless of their fundamental position on abortion. As such, the pragmatic reason can engender broader support for legal tolerance of conscientious objections to abortion than the deontological reason. ${ }^{23}$ Whenever lawmakers opt for legal tolerance of contested beliefs, opinions and practices, it is thus in their interest to base these policies on pragmatic grounds. This is, as I am about to show, what lawmakers in fact tend to do.

\section{Pragmatic Legal Tolerance in Practice}

The schizophrenic combination of disapproval and permission that is characteristic of legal tolerance, entails that legal tolerance cannot be pervasive. The alternative would leave legal systems with the equivalent of dissociative identity disorder. Nevertheless, as I intend to show in this section, a remarkable range of legal policies in an array of jurisdictions can be

\footnotetext{
${ }^{23}$ Assuming, of course, that lawmakers actually favour a policy of legal tolerance over one of, for instance, prohibition. As indicated earlier and repeated in the conclusion, in this article I do not provide normative arguments on the desirability of legal tolerance over policies of legalization and prohibition. My aims are, instead, largely descriptive.
} 
subsumed under the analytical structure of legal tolerance. I will further show that lawmakers tend to base policies of legal tolerance on pragmatic grounds.

Throughout this section, I discuss policies of legal tolerance on issues as varied as prostitution, tobacco use, marijuana consumption, hate speech, blasphemy, conscientious objection to abortion and conscientious objection to same-sex marriage. Among these examples, two different scenarios can be discerned. Although both scenarios can be categorized as instances of legal tolerance, such categorization is more controversial in relation to one scenario than the other.

Let us first examine the straightforward, uncontroversial scenario. In some of the examples that are discussed below, state authorities de facto permit practices that are de jure illegal (this is the case for prostitution, marijuana consumption, and blasphemy). ${ }^{24}$ Categorizing these cases as instances of legal tolerance is uncontroversial, as both components of tolerance - disapproval and permission - are clearly present. Prohibitions in criminal law underscore the objectionable nature of a practice, signalling state disapproval in the law on the books. Yet, the criminal law is intentionally left unenforced. In other words, the law in action permits the practice. This dichotomy between the law on the books (disapproval) and the law in action (permission) creates space for legal tolerance. Recall the marijuana example introduced above.

In the more difficult scenario, the converse occurs: state authorities disapprove of practices that are entirely legal. In this scenario, the criminal law does not - not even qua law on the books - coercively interfere with the practice (this is the case for tobacco use, hate speech, and conscientious objection to abortion). At first blush, there are no markers of legal tolerance here. Consider, for instance, conscience clauses in abortion legislation that allow the

\footnotetext{
${ }^{24}$ Ybo Buruma, 'Dutch Tolerance: On Drugs, Prostitution, and Euthanasia' (2007) 35 Crime and Justice 73, 85.
} 
exercise of conscientious objections by doctors. Here, there appears to be no dichotomy between the law on the books and the law in action. After all, the contested practice is entirely legal.

I will nevertheless argue, in due course, that these and other practices may also be the object of legal tolerance. Markers of tolerance might be less obvious, but they are nonetheless present. In the absence of criminal prohibitions, the disapproval that distinguishes legal tolerance from acceptance or indifference is, however, more difficult to identify. But disapproval can often be discerned in state communicative action, through which lawmakers signal that certain practices are 'merely' tolerated and nothing more. In other words, in this scenario the law on the books permits, while the law in action signals disapproval. Since both analytical components of tolerance remain present, these cases can also be categorized as instances of legal tolerance. $^{25}$

In testing the pragmatic case for legal tolerance, I analyse, in that order, legal tolerance of contested 'life choices' (prostitution, marijuana consumption and tobacco use), divisive speech acts (hate speech and blasphemy) and religious conscience (conscientious objection to abortion and same-sex marriage). Although I draw on examples from a relatively broad range of countries, I do not have legal-comparative ambitions. All I intend to show is that policies of legal tolerance can be found in a wide array of jurisdictions. Where instructive, I indicate that other countries have opted against legal tolerance. In the conclusion, I briefly explore the assumptions that separate both sets of responses.

\footnotetext{
25 The distinction between both instances - illegal but de facto permitted; and legal but disapproved of - is strictly analytical in that both instances can be categorized as legal tolerance, despite their different structure. There is no substantive difference between both situations. The distinction nevertheless remains relevant to the analysis in that it for instance explains why the role of state communicative power is discussed below (see section 4).
} 


\section{A. Legal Tolerance of Contested 'Life Choices': Prostitution, Marijuana}

\section{Consumption and Tobacco Use}

Instrumental arguments for tolerance of prostitution have a long pedigree. As far back as the $4^{\text {th }}$ century, St. Augustine disparagingly described 'prostitutes ${ }^{26}$ as a 'type of human being, whose morals carry impurity to its lowest depths' ${ }^{27}$ But he also thought that 'according to the laws of general order' it was inevitable that they would continue to occupy 'a place ... at the heart of society', if 'certainly the most vile place' ${ }^{28}$ Augustine argued that prostitution should be tolerated, but only for (extremely sexist) instrumental reasons: '[i]f one suppresses prostitutes, the passions will convulse society; [whereas] if one gives them the place that is reserved for honest women, everything becomes degraded in defilement and ignominy ${ }^{29}$

Throughout much of history, Augustinian tolerance of prostitution dominated legal policy. In $19^{\text {th }}$ century France, for instance, prostitution was still tolerated as a 'necessary evil' and treated analogous to dissection theatres and cesspools (other objects of disgust that were considered 'necessary evils'). ${ }^{30}$ But legal tolerance of prostitution also served pragmatic ends in that it enabled state control over safety and hygiene: madames were responsible for registering 'prostitutes' in their employ and state agents conducted regular brothel inspections. ${ }^{31}$ Similar policies of legal tolerance of prostitution were in place in other countries, like the Netherlands and the United States. ${ }^{32}$

\footnotetext{
${ }^{26}$ I feel ambivalent about using the term 'prostitute' and will try to avoid it (although I cannot avoid the term 'prostitution' as an object of tolerance). I introduce the term 'sex worker' further on, to indicate the difference between legal policies of tolerance (of 'prostitutes') and acceptance (of sex workers).

${ }^{27}$ Alain Corbin, 'Commercial Sexuality in Nineteenth-Century France: A System of Images and Regulations' (1986) 14 Representations 209, 213.

28 ibid 213-14.

${ }^{29}$ ibid 213.

30 ibid 214.

31 ibid 216.

32 Ann Lucas, 'Race, Class, Gender, and Deviancy: The Criminalization of Prostitution' (1995) 10 Berkeley Women's LJ 47, 50-51 (discussing $19^{\text {th }}$ century United States); Chrisje Brants, 'The Fine Art of Regulated Tolerance: Prostitution in Amsterdam' (1998) 25 J Law and Soc 621, 621 (discussing the Netherlands, and Amsterdam in particular, in early $15^{\text {th }}$ century).
} 
In some of these countries, however, tolerance of prostitution was eventually substituted with prohibitionist laws and policies. The United States, for instance, moved from tolerance to prohibition of prostitution during the Progressive Era (1890s to 1920 s) ${ }^{33}$ This change in legal policy was driven by fear of changes in the family structure and the role of women, as well as the spread of syphilis, all of which were blamed on the persistence of prostitution. ${ }^{34}$ Other states, including Sweden and Norway, have recently also adopted a prohibitionist approach. ${ }^{35}$ In 1998, Sweden legislated to prohibit prostitution. Acts of selling sex remain legal (except, revealingly, for migrant women), ${ }^{36}$ but everything surrounding those acts has been criminalized, including purchasing sex. ${ }^{37}$ 'By adopting the legislation', the Swedish government explained, 'Sweden has given notice to the world that it regards prostitution as a serious form of oppression of women and children and that efforts must be made to combat it'. ${ }^{38}$

In other countries, however, legal tolerance of prostitution - eventually freed from the Augustinian moralizing that originally attended such tolerance ${ }^{39}-$ has remained in force. The Netherlands is probably the most notorious example. Although the Netherlands is often associated with libertarian views on issues like sex work and marijuana consumption, its laws and policies are much closer aligned to legal tolerance than free-for-all permission. As we will

\footnotetext{
${ }^{33}$ Lucas (n 32) 50-51.

${ }^{34}$ ibid 53 and 55. Sex work remains illegal in almost the entire United States (save for 11 counties in Nevada). See ProCon, 'US Federal and State Prostitution Laws and Related Punishments' (2018) <https://prostitution.procon.org/view.resource.php?resourceID=000119> accessed 20 March 2018.

35 Jane Scoular, 'What's Law Got To Do With It? How and Why Law Matters in the Regulation of Sex Work' (2010) $37 \mathrm{~J}$ Law and Soc 12, 17.

36 May-Len Skilbrei and Charlotta Holmström, 'The "Nordic model" of prostitution law is a myth' (The Conversation, 16 December 2013), <https://theconversation.com/the-nordic-model-of-prostitution-law-is-amyth-21351> accessed 20 March 2018.

${ }^{37}$ Scoular (n 35) 17.

38 ibid $17-18$.

39 In $15^{\text {th }}$ century Amsterdam, for instance, the Augustinian 'necessary evil' perspective on prostitution dominated. See Brants (n 32) 621 (citing a city of Amsterdam bye-law: 'Because whores are necessary in big cities (...) and also because the holy church tolerates whores on good grounds ... the court and sheriff of Amsterdam shall not entirely forbid the keeping of brothels.').
} 
see below, this remains true in relation to marijuana consumption. But until 2000, it was also true for prostitution.

Prior to 2000, acts of offering and purchasing sex for money were already legal in the Netherlands, but procuring and running a brothel remained criminal offenses. ${ }^{40}$ Despite their illegality, however, brothels were tolerated in designated areas: the famous red-light districts in cities like Amsterdam. ${ }^{41}$ Street prostitution as well was formally illegal, but tolerated in limited areas - so-called tippelzones - in several Dutch cities. Public prosecutors utilized their discretionary power under the law to refrain from prosecuting much prostitution-related crime, as strict law enforcement was not considered necessary to protect the public interest. ${ }^{42}$ In terms of the different scenarios of legal tolerance identified earlier, the pre-2000 legal policy of the Netherlands thus falls in the category of illegal, but de facto permitted practices. ${ }^{43}$ In other words, this is an instance in which the law in action permits a practice that is disapproved of in the law on the books.

Moreover, prostitution was largely tolerated for pragmatic reasons. ${ }^{44}$ In the face of a centuries-old practice that was unlikely to disappear - and towards which societal views were shifting in the direction of acceptance ${ }^{45}$ - the Netherlands considered it prudent to enable some measure of state control. ${ }^{46}$ By enacting official policies of legal tolerance of prostitution, the authorities diverted 'a great deal of crime ... away from the criminal justice system proper'. ${ }^{47}$ Simultaneously, 'with the criminal law as a threat in the background', they gained

\footnotetext{
40 ibid 623-24.

${ }^{41}$ Joyce Outshoorn, 'Pragmatism in the Polder: Changing Prostitution Policy in The Netherlands' (2004) 12 J Cont Eur Stud 165, 170.

${ }^{42}$ Wim Huisman and Edward R Kleemans, 'The Challenges of Fighting Sex Trafficking in the Legalized Prostitution Market of the Netherlands' (2014) 61 Crime, L \& Soc Change 215, 219.

${ }^{43}$ See text to $n 24$.

${ }^{44}$ Outshoorn (n 41) 174.

${ }^{45}$ Brants (n 32) 630 (citing a 1997 study finding that $74 \%$ of the Dutch population considered prostitution an acceptable job).

${ }^{46}$ Outshoorn (n 41) 174-75.

${ }^{47}$ Brants (n 32) 624.
} 
the power to regulate the market (eg through hygiene and identity checks during brothel inspections). ${ }^{48}$

In 2000, however, the Netherlands made the opposite move to Sweden. Rather than substitute prohibition for legal tolerance, it opted for legalization. The criminal ban on brothels was abolished, making all aspects of prostitution entirely legal (barring associated crimes like trafficking in human beings, which of course remain illegal). The question that arises is the following: is prostitution-turned-sex-work now accepted as 'just another profession' in the Netherlands? Or has one form of legal tolerance merely replaced the other? In other words, has legal policy in the Netherlands merely moved from one category of legal tolerance - illegal but de facto permitted - to the other category - legal, but still disapproved of? Or has it escaped the confines of legal tolerance altogether to come within the ambit of respect, where disapproval is replaced with acceptance?

Some terminological markers point in the latter direction. The Dutch police, for instance, notes on its official webpage that brothel owners, procurers and sex workers 'are seen by the law as regular employers and employees'. ${ }^{49}$ Whereas 'prostitutes' were tolerated, 'sex workers' are - so it seems - respected. Other markers, however, continue to point in the former direction, rendering the precise nature of legal policy ambivalent. ${ }^{50}$ All aspects of sex work may now be legal in the Netherlands, but they are also restrictively regulated. Crucially, sex work outside the regulated areas, including street prostitution, is no longer tolerated. ${ }^{51}$ On balance, the Netherlands could be in a transitional phase, in which sex work is fully legalized, but continues to be tolerated qua prostitution in a state-regulated space that is clearly

\footnotetext{
${ }^{48}$ Huisman and Kleemans (n 42) 215 and 217 (but finding that attempts to combat sex trafficking have failed).

${ }^{49}$ Politie, 'Prostitutie' <www.politie.nl/themas/prostitutie.html> accessed 20 March 2018 (official website of the Dutch police).

${ }^{50}$ See also Huisman and Kleemans (n 42) 225 ('Legalization does not mean that prostitution is accepted').

${ }^{51}$ Scoular (n 35) 20-21.
} 
delineated from the rest of the public sphere, in which prostitution is not tolerated. ${ }^{52}$ Other countries, such as Belgium, in any event continue to implement the clearer policy of legal tolerance of prostitution: illegal, but de facto permitted in certain areas. ${ }^{53}$

Like prostitution, marijuana consumption is the object of diverging regulatory regimes in different countries. In Uruguay, Canada and several US states, for instance, the production, sale and consumption of marijuana are legal. ${ }^{54}$ At the federal level in the US, however, marijuana is criminalized and the object of strict enforcement policies under the current administration. ${ }^{55}$ In countries like the Netherlands, finally, the sale and possession of marijuana is illegal, but prosecutorial policies of non-enforcement are in place, up to a certain threshold. ${ }^{56}$ In the Netherlands, the sale and consumption of marijuana is thus tolerated. And it is tolerated for pragmatic reasons.

Unlike under US federal law, where marijuana is listed along with heroin and MDMA on the schedule of substances that have 'a high potential for abuse' and 'no currently accepted medical use', ${ }^{57}$ in the Netherlands the 'soft drug' marijuana is listed on a different schedule

\footnotetext{
52 ibid; Brants (n 32) 634 (speculating, in 1998, that legalization would lead to the emergence of 'a new system of regulated tolerance').

${ }^{53}$ In Belgium, both procurement of prostitution and running a brothel are criminal offenses. See Criminal Code, Article 380 (1) (inserted in 1914). Yet, zones of legal tolerance (red-light districts) exist in cities like Antwerp and Ghent. In Australia, laws and policies on prostitution differ from state to state. But those in Western Australia are analogous to - if more restrictive than - the Dutch policy of legal tolerance prior to 2000. In Western Australia, acts of prostitution are legal, but offering or seeking paid sex is illegal when it takes place 'in or in the view or within hearing of a public place'. See Prostitution Act 2000 (Western Australia), s 5 and s 6. Running a brothel is illegal in all circumstances. See Criminal Code Act Compilation Act 1913 (Western Australia), s 190. De facto, however, brothels seem to be tolerated in non-residential areas. See Basil Donovan and others, The Sex Industry in Western Australia: A Report to the Western Australian Government (University of New South Wales 2010) 34 <https://kirby.unsw.edu.au/sites/default/files/kirby/report/SHP_WA-SexIndustry-Report-2010.pdf > accessed 20 March 2018.

${ }^{54}$ Ley No. 19.172 Marihuana y sus derivados (Uruguay); Cannabis Act 2018 (Canada); Avantika Chilkoti, 'States Keep Saying Yes to Marijuana Use. Now Comes the Federal No' New York Times (15 July 2017) <www.nytimes.com/2017/07/15/us/politics/marijuana-laws-state-federal.html?mcubz=1> accessed 20 March 2018.

${ }^{55}$ Jamiles Lartey, 'Jeff Sessions to crack down on legalized marijuana, ending Obama-era policy' The Guardian (5 January 2018) <www.theguardian.com/us-news/2018/jan/04/jeff-sessions-to-crack-down-on-legalizedmarijuana-ending-obama-era-policy $>$ accessed 20 March 2018.

${ }^{56}$ Similar policies of legal tolerance - but limited to the possession of marijuana and not its sale - are in place in Belgium.

${ }^{57}$ Drug Enforcement Administration, 'Drug Scheduling' <www.dea.gov/druginfo/ds.shtml> accessed 20 March 2018.
} 
from 'hard drugs' like heroin and MDMA. ${ }^{58}$ The Netherlands thereby recognizes that soft drugs (eg marijuana) are less dangerous than hard drugs (eg heroin). ${ }^{59}$ Although production, sale and possession of both sets of drugs are illegal, ${ }^{60}$ prosecutorial guidelines are in place to tolerate the sale and possession of marijuana, within limits. ${ }^{61}$ On this system of legal tolerance, individuals are not prosecuted when they are in possession of up to five grams of marijuana. ${ }^{62}$ The sale of marijuana in so-called coffee shops is similarly tolerated, ${ }^{63}$ under strict regulatory conditions (eg not selling to minors; no advertising; and not granting access to non-residents of the Netherlands). ${ }^{64}$

Despite outside assumptions to the contrary, the sale and possession of marijuana are not openly accepted in the Netherlands. ${ }^{65}$ Rather, the legal policy is one of tolerance: the criminal law on the books is deliberately left unenforced in practice. Dutch law in action tolerates the sale and possession of marijuana for two interconnected pragmatic reasons. First, soft drugs are seen as less dangerous than hard drugs. ${ }^{66}$ This makes it feasible to tolerate their consumption, while reserving the brute force of the criminal justice system to tackle the hard drugs market. ${ }^{67}$ Second, it is thought prudent to keep the soft drugs and hard drugs markets clearly separated. ${ }^{6}$ Tolerating the sale of marijuana in coffee shops serves to generate that

\footnotetext{
58 Rijksoverheid, 'Wet Maakt Verschil tussen Harddrugs en Softdrugs' <www.rijksoverheid.nl/onderwerpen/drugs/wet-maakt-verschil-harddrugs-en-softdrugs> accessed 20 March 2018 (official website of the Dutch government, for the distinction between 'soft drugs' and 'hard drugs').

59 ibid.

${ }^{60}$ Opium Act 1928, Articles 2 and 3 (prohibiting, in identical terms, the sale, production and possession of both sets of drugs).

61 Rijksoverheid, 'Gedoogbeleid Softdrugs en Coffeeshops' <www.rijksoverheid.nl/onderwerpen/drugs/gedoogbeleid-softdrugs-en-coffeeshops> accessed 20 March 2018 (official webpage of the Dutch government; for the policy of legal tolerance of 'softdrugs').

62 ibid. The drugs, however, will be confiscated by the police. See <www.om.nl/onderwerpen/boetebase/?boete_tree=21924,21917\#beslissingpad2192421917> accessed 20 March 2018 (website of the Dutch public prosecutor's office). This confirms that the policy is one of legal tolerance rather than acceptance.

63 But purchasing marijuana, including by coffee shops, remains illegal. This implies persistent criminal profitability of production and sale of marijuana.

${ }^{64}$ Rijksoverheid (n 61).

${ }^{65}$ Buruma (n 24) 92.

${ }^{66}$ Rijksoverheid (n 58).

${ }^{67}$ Buruma (n 24) 90.

68 ibid.
} 
separation. The authorities' assumption is that by granting individuals legal avenues to purchase marijuana in coffee shops, they can keep those individuals away from the more dangerous hard drugs (as well as the criminal elements that distribute them) ${ }^{69}$ As with prostitution prior to 2000 , however, the threat of criminal law remains present. The Dutch authorities thus retain the option of prosecuting coffee shops that violate the terms of the tolerance pact. ${ }^{70}$

Tobacco use, finally, differs significantly - at first sight at least - from sex work and marijuana consumption, in that it has always been legal. Smoking is clearly not the object of legal tolerance of the first type: illegal, but permitted. But I want to suggest that it does fall in the second category of legal tolerance: legal, but disapproved of. Smoking has become less and less accepted as knowledge of its harmful effects (both primary and secondary) has increased. Most countries subject tobacco use to a growing array of restrictions and regulations. These are driven by the harms caused by, as well as costs associated with, tobacco use. Self-harm, in the sense that tobacco use steeply increases risks of cancer, goes hand in hand with a rise in public health costs. Both have prompted legal measures such as tax increases and mandatory display of warning messages on tobacco products. But only when third-party harm caused by secondary smoking became undeniable, did the physical space in which the use of tobacco was accepted begin to shrink. In many countries, smoking is now legally banned from restaurants, bars, train stations and all manner of public places. Tobacco users are often relegated to segregated areas of the public sphere, analogous to red-light districts. $^{71}$

\footnotetext{
${ }^{69}$ ibid; Eric Blumenson and Eva Nilsen, 'No Rational Basis: The Pragmatic Case for Marijuana Law Reform' (2009) 17 Va J Soc Pol'y \& L 43, 78.

${ }^{70}$ Rijksoverheid (n 61).

${ }^{71}$ This is an overstatement, since anyone can smoke in the streets whereas street sex work is increasingly curbed. But it does apply in other public spaces, such as airports that have installed smoking booths.
} 
Although a growing number of states has opted to strictly regulate the use of tobacco, none (so far) has banned it. ${ }^{72}$ Tobacco use is thus no longer openly accepted, but it is not prohibited either. Instead, it has become the object of legal tolerance. Legal tolerance of the use of tobacco is arguably spurred by two reasons, only one of which is pragmatic. First, there is a deontological, autonomy-based reason linked to the self-harm caused by smoking. In liberal democracies, anti-paternalism acts as a strong deontological reason against prohibiting practices that cause self-harm. Paternalism is generally considered problematic, because it obstructs personal autonomy. It is arguably out of deference to personal autonomy, at least in part, that states have not (yet) opted to ban smoking outright.

Tobacco use, however, also causes third-party harm. And this is where pragmatic (as opposed to deontological) reasons for legal tolerance come in. Lawmakers tolerate tobacco use despite its strong potential to cause third-party harm, because it is a longstanding and widespread practice that is unlikely to just go away. Past failed attempts at prohibition of alcohol have moreover demonstrated that the prohibitionist approach is unlikely to succeed. Given the addictive properties of nicotine, prohibitionist policies are even more liable to create space for a flourishing criminal market for tobacco products than was the case under alcohol prohibition. Combine this with longstanding - if rapidly changing - social acceptance of smoking, and policies of legal tolerance certainly seem more prudent than prohibition. As we are about to see, (resistance to) change is also central to legal tolerance of divisive speech acts.

\section{B. Legal Tolerance of Divisive Speech Acts: Hate Speech and Blasphemy}

\footnotetext{
${ }^{72}$ Note that the Holy See recently banned the sale of cigarettes in the Vatican City State. See Gaia Pianigiani, 'White Smoke from the Vatican? Not from Cigarettes' New York Times (9 November 2017) <www.nytimes.com/2017/11/09/world/europe/pope-francis-vatican-cigarettes.html> accessed 20 March 2018.
} 
Two types of speech acts - hate speech and blasphemy - are particularly divisive in ethnically and religiously diverse societies, which most if not all constitutional democracies are. Legal responses to one of those speech acts (blasphemy) have transitioned from prohibition to acceptance in most constitutional democracies, at least in 'the West'. For a long time, Ireland remained a notable exception by retaining a criminal ban on blasphemous speech. Following a recent constitutional referendum, however, Ireland has now abolished the 'constitutional crime' of blasphemy. ${ }^{73}$ But even before the recent constitutional change, I argue below, blasphemy was already the object of legal tolerance in Ireland, not flat-out prohibition.

Quite the converse of blasphemy is true of hate speech. In responding to hate speech, most constitutional democracies have opted not to tolerate the intolerant. Hate speech is prohibited - and patently not tolerated - in most Western constitutional democracies. The United States is the famous outlier. ${ }^{74}$ But although hate speech is legal in the United States, ${ }^{75}$ it is certainly not accepted as inherently valuable speech. Instead, it is the object of legal tolerance. ${ }^{76}$ Hate speech is legal in the United States, but deeply disapproved of.

Under US constitutional law, neo-Nazi marches - whether in Skokie in 1978 or Charlottesville in 2017 - cannot be banned because of their hateful content. ${ }^{77}$ The same goes for cross-burning on the lawns of black-American families. ${ }^{78}$ This is so because the First

\footnotetext{
${ }^{73}$ On 28 October 2018, the Irish people voted overwhelmingly, in a constitutional referendum, to abolish the 'constitutional crime' of blasphemy. See Patsy McGarry, 'Ireland votes as one to remove blasphemy from Constitution' The Irish Times (28 October 2018) <www.irishtimes.com/news/social-affairs/religion-andbeliefs/ireland-votes-as-one-to-remove-blasphemy-from-constitution-1.3678935> accessed 29 October 2018.

${ }^{74}$ Sionaidh Douglas-Scott, 'The Hatefulness of Protected Speech: A Comparison of the American and European Approaches' (1998) 7 Wm \& Mary Bill Rts J 305; Michel Rosenfeld, 'Hate Speech in Constitutional Jurisprudence: A Comparative Analysis' (2002) 24 Cardozo L Rev 1523.

${ }^{75}$ For current purposes, hate speech is speech that expresses or incites hatred against (members of) a group, based on an identifiable characteristic such as (perceived) race or ethnicity, but that falls short of incitement to imminent lawless action (eg incitement to imminent violence). Under US first amendment law, the latter is not constitutionally protected speech whereas the former is. See Brandenburg v Ohio, 395 U.S. 444 (1969).

${ }^{76}$ Michel Rosenfeld, 'Pragmatism, Pluralism, and Legal Interpretation: Posner's and Rorty's Justice without Metaphysics Meets Hate Speech' (1996) 18 Cardozo L Rev 97, 141 ('The dominant position in the United States [is that] extremist or hate speech that falls short of 'fighting words' or (...) incitement to violence ought to be tolerated').

77 Village of Skokie v National Socialist Party of America 69 Ill. 2d 605 (IL 1978).

${ }^{78}$ R.A.V. v City of St. Paul 505 U.S. 377 (1992).
} 
Amendment to the US Constitution, as interpreted by the Supreme Court, prohibits most content-based restrictions on speech: '[t]he First Amendment generally prevents government from proscribing speech (...) because of disapproval of the ideas expressed' ${ }^{79}$ Tolerance plays a key role in supporting this - comparatively speaking - extreme take on free speech. As the Supreme Court puts it, 'in public debate [we] must tolerate insulting, and even outrageous, speech in order to provide adequate "breathing space" to the freedoms protected by the First Amendment' ${ }^{80}$

Hate speech is thus legal in the United States. But this does not imply that lawmakers are indifferent towards hate speech, let alone accept it. ${ }^{81}$ Instead, hate speech is the object of legal tolerance. This transpires from the language of disapproval utilized by the courts that ruled on the neo-Nazi march in Skokie and the cross-burning in St. Paul. In both cases, the courts found the content-based restrictions on hate speech unconstitutional. But in both cases, they also expressed their (deep) disapproval of the hateful messages.

In the cross-burning case, the justices of the Supreme Court ruled that confronting racists beliefs could not 'consist of selective limitations upon speech'. ${ }^{82}$ Yet they also took pains to emphasize their 'belief that burning a cross in someone's front yard is reprehensible'. ${ }^{83}$ In the neo-Nazi march case, the judges of the Court of Appeals for the Seventh Circuit went to great lengths 'to express [their] repugnance at the doctrines' of the National Socialist Party of America. ${ }^{84}$ The judges described those doctrines as 'generally

\footnotetext{
79 ibid 382. See also Snyder v Phelps 562 U. S. (2011), 11 (citing Texas $v$ Johnson to the effect that '[i]f there is a bedrock principle underlying the First Amendment, it is that the government may not prohibit the expression of an idea simply because society finds the idea itself offensive or disagreeable.').

${ }^{80}$ Snyder (n 79) 11 (citing Boos v Barry).

${ }^{81}$ ibid ('The state's protection of these viewpoints, however, is not equivalent to the state's indifference to them.').

82 ibid.

83 R.A.V. (n 78) 396. They further endorsed the Supreme Court of Minnesota's view that '[i]t is the responsibility, even the obligation, of diverse communities to confront [messages based on virulent notions of racial supremacy] in whatever form they appear'. See ibid 392.

${ }^{84}$ Collin v Smith, 578 F.2d 1197 (1978) 1210.
} 
unacceptable ${ }^{85}$ and 'repugnant to the core values held generally by residents of this country and, indeed, to much of what we cherish in civilization' ${ }^{86}$ Nevertheless, they concluded that the Constitution demanded that the hate speech be tolerated: 'if these civil rights are to remain vital for all, they must protect not only those society deems acceptable, but also those whose ideas it quite justifiably rejects and despises', ${ }^{87}$

Several rationales have been invoked to justify the ban on most content-based restrictions of speech in US first amendment law. Some of these justifications, such as the rationale from autonomy, ${ }^{88}$ are clearly deontological and will not be considered here. Two other influential rationales, which can also sustain legal tolerance of hate speech, are instrumental. ${ }^{89}$ But only one of these rationales is also pragmatic in the sense intended in this article.

Both instrumental rationales relate to the search for truth in 'the free marketplace of ideas'. ${ }^{90}$ The first rationale is optimistic (or idealistic). It assumes that the free expression of all ideas, even patently false ones like racist beliefs, contributes to the discovery of truth. ${ }^{91}$ The second rationale, which 'has been dominant' ever since it was first formulated by Justice Holmes,${ }^{92}$ is sceptical (or pessimistic). ${ }^{93}$ Also known as 'the fortress model', ${ }^{94}$ the pessimistic

\footnotetext{
85 ibid 1199.

${ }^{86}$ ibid 1200.

87 ibid 1210

${ }^{88}$ See, for instance, Charles Fried. 'The New First Amendment Jurisprudence: A Threat to Liberty' (1992) 59 U Chi L Rev 225.

${ }^{89}$ For an alternative tolerance-based rationale, see Lee Bollinger, The Tolerant Society (OUP 1986).

${ }^{90}$ Rosenfeld (n 74) 1533-34 and 1536.

${ }^{91}$ See, for instance, Collin (n 84) 1203 ('Under the First Amendment there is no such thing as a false idea. However pernicious an opinion may seem, we depend for its correction not on the conscience of judges and juries but on the competition of other ideas.').

92 Rosenfeld (n 74) 1534. See, for instance, Village of Skokie (n 77) 614, citing Cohen v California ('we think it is largely because governmental officials cannot make principled distinctions in this area that the Constitution leaves matters of taste and style so largely to the individual').

${ }^{93}$ Rosenfeld (n 74) 1534; Vincent Blasi, 'The Teaching Function of the First Amendment' (1987) 87 Columbia Law Review 387, 395.

${ }^{94}$ Blasi (n 93) 394 (ascribing the term to Lee Bollinger).
} 
account is sceptical of the idea of truth. ${ }^{95}$ It is based on the notion that any idea can be false; and most likely is. ${ }^{96}$

The primary concern of both the optimistic and the sceptical rationale is with the threat of overbreadth attending government regulation of speech. ${ }^{97}$ On both accounts, hate speech is tolerated for instrumental reasons: ${ }^{98}$ either to not jeopardize the free search for truth or to avoid a sliding scale on which the government inevitably ends up restricting valuable speech, however commendable its original intentions are. ${ }^{99}$ Crucially, however, only one of these instrumental reasons is also pragmatic in the sense intended in this article. The 'free search for truth' rationale does not qualify as a pragmatic reason, since it rests on the divisive assumption that hateful speech should be tolerated because it can somehow contribute to the discovery of truth. Yet this alleged truth-finding capability of all speech, even hate speech, is precisely what opponents of hate speech reject. The 'free search for truth' rationale can thus hardly supply a shared practical reason to which both sides of the moral controversy on hate speech can subscribe.

Arguably, however, the sceptical rationale of 'the fortress model' does supply such a shared practical reason. On the Holmesian view, the government cannot be trusted with the power to decide which ideas are true (and can thus be uttered) and which are false (and can

\footnotetext{
95 Rosenfeld (n 74) 1534.

${ }^{96}$ Michel Rosenfeld, 'Extremist Speech and the Paradox of Tolerance' (1987) 100 Harv L Rev 1457, 1467.

${ }^{97}$ See R.A.V. (n 78) 387 ('The rationale of the general prohibition ... is that content discrimination "raises the specter that the Government may effectively drive certain ideas or viewpoints from the marketplace".' [internal citations omitted]).

${ }_{98}$ A possible counterargument claims that legal tolerance is not available on the sceptical account, because tolerance entails disapproval, which in turn presupposes knowledge that certain opinions - in this case racist beliefs - are false. See Yossi Nehushtan, 'The Limits of Tolerance: A Substantive-Liberal Perspective' (2007) 20 Ratio Juris 230, 242. I doubt, however, that the last premise in the counterargument is accurate. There is no reason to assume that only views that are known to be false can be disapproved of (and thus tolerated). But even if the counterargument sticks, it only precludes legal tolerance on what Steven Smith terms 'strong scepticism', on which no view can ever be known to be false. The account offered in the text remains compatible with what Smith terms 'weak scepticism'. On the weak sceptical argument, we can know with 'practical certainty' that certain ideas are false (racist beliefs would fall in this category). See Steven Smith, 'Scepticism, Tolerance, and Truth in the Theory of Free Expression' (1986) 60 S Cal L Rev 649.

${ }^{99}$ Rosenfeld (n 96) 1467; Blasi (n 93) 388 and 394.
} 
therefore be silenced), because it is likely to rely on false ideas in making that determination. ${ }^{100}$ The antidote of the fortress model is 'to overprotect speech' ${ }^{\text {'01 }}$ by erecting a 'doctrinal buffer zones'. ${ }^{102}$ Legal tolerance of hate speech resides in that buffer zone. Such legal tolerance is supported by a pragmatic reason on the negative consequences attending overzealous regulation of speech by the government. Since these negative consequences could affect everyone equally, their avoidance is a shared practical reason to which both sides of the hate speech controversy can, in principle, subscribe. ${ }^{103}$ Of the reasons invoked to support legal tolerance of hate speech in US first amendment law, the pragmatic reason supplied by 'the fortress model' is thus arguably the least divisive (and in that sense the best).

Whereas hate speech is subject to prohibitionist laws in most constitutional democracies, but tolerated in a few (or a single), the opposite is true of blasphemy. In 'the West', at least, criminal bans on blasphemy have largely been repealed. Blasphemous speech is now accepted as an integral part of public debate. ${ }^{104}$ Nevertheless, a few outlier states and regions long retained criminal bans on blasphemy. ${ }^{105}$ From the vantage point of legal tolerance, those states and regions are of special interest. Although criminal bans on blasphemy persisted on the books in these places, they were not enforced in practice. In the most prominent example - Ireland - legal tolerance of blasphemy moreover acted as a transitional measure between a past of prohibition and a future of acceptance.

For a long time, the Constitution of Ireland stated, in the same provision that ensures freedom of expression, that ' $[\mathrm{t}]$ he publication or utterance of blasphemous ... matter is an

\footnotetext{
100 Posner (n 20) 1661-62.

${ }^{101}$ Rosenfeld (n 96) 1467.

102 Blasi (n 93) 394.

${ }^{103}$ But see a caveat on the assumptions implicit in this view, in the conclusion.

104 By blasphemous speech, I mean speech that denies the 'truth' in religious scripture, criticizes religious doctrine or deprecates god(s) and/or key religious figures.

105 In Northern Ireland and Scotland, for instance, blasphemy remains a common law offense. But the last prosecution for blasphemy in Scotland occurred in 1843 and there are no reported cases of prosecution for blasphemy at all in Northern Ireland. See Law Library of Congress, 'Blasphemy and Related Laws in Selected Jurisdictions' (2017) 22 and 24-25 <www.loc.gov/law/help/blasphemy/blasphemy.pdf> accessed 20 March 2018.
} 
offence which shall be punishable in accordance with law'. ${ }^{106}$ Blasphemy was thus a 'constitutional crime' in Ireland. ${ }^{107}$ In a recent constitutional referendum, however, the Irish people voted overwhelmingly to remove the crime of blasphemy from their Constitution. ${ }^{108}$

But even before the constitutional referendum, blasphemy was not outright prohibited in Ireland. There might have been a 'constitutional crime' of blasphemy on the books, but blasphemous speech was the object of legal tolerance in practice. The clearest evidence of this is that the last recorded prosecution for blasphemy in the country dates to $1855 .{ }^{109}$ Even the defendant in that case was acquitted, because he clearly did not intend to blaspheme. ${ }^{110}$ When the next case came along in 1999, the Supreme Court of Ireland refused to authorize a criminal prosecution for publication of an allegedly blasphemous cartoon. ${ }^{111}$ 'There is no doubt that the crime of blasphemy exists as an offence in Irish Law because the Constitution says so', the Supreme Court held. ${ }^{112}$ But since the crime was not defined in the constitution or ordinary legislation, the Supreme Court could not order its prosecution: 'in the absence of any legislative definition of the constitutional offence of blasphemy, it is impossible to say of what the offence of blasphemy consists'. ${ }^{113}$

The definitional obstacle was eventually overcome with the 2009 Defamation Act. Under section 36 of the Act, a person committed blasphemy when she intentionally caused outrage among a substantial number of adherents of a religion by publishing or uttering

\footnotetext{
${ }^{106}$ Constitution of Ireland, Article 40.6(1), as it existed prior to the constitutional referendum.

${ }^{107}$ Neville Cox, 'Sacrilege and Sensibility: The Value of Irish Blasphemy Law' (1997) 19 Dublin ULJ 87, 88.

${ }^{108}$ McGarry (n 73). The constitutional referendum on blasphemy followed earlier referenda on other (previously) contested issues, in which the Irish people voted to introduce same-sex marriage and to remove the constitutional ban on abortion (which had taken the form of a constitutional right to life of the unborn).

109 ibid.

${ }^{110}$ The defendant, a priest, had encouraged his parishioners to bring him 'evil' literature to burn on a bonfire in his chapel yard. Among the pile of books that were handed in was, unknown to the priest, a copy of the bible. The priest thus accidentally burned a bible. He was prosecuted for blasphemy, but acquitted. See Corway $v$ Independent Newspapers [1999] 4 IR 485 (summarizing the case).

111 ibid.

112 ibid.

113 ibid.
} 
statements that are grossly abusive or insulting of matters held sacred by that religion. ${ }^{114}$ For a while then, the 'constitutional crime' of blasphemy was implemented in ordinary legislation.

But the consensus in Ireland was that section 36 of the Defamation Act 2009 was 'essentially unenforceable'115 and the offense 'virtually impossible to prosecute'. ${ }^{116}$ Technically, blasphemy was still prohibited under Irish criminal law. ${ }^{117}$ In practice, however, it was the object of legal tolerance. ${ }^{118}$ As the recent constitutional referendum moreover shows, legal tolerance of blasphemy in Ireland acted as a transitional measure between a (distant) past of prohibition and a (certain) future of acceptance of 'blasphemous' speech. ${ }^{119}$ I discuss the transitional nature of legal tolerance further in section 4.

\section{Legal Tolerance of Religious Conscience: Abortion and Same-sex Marriage}

\footnotetext{
${ }^{114}$ Defamation Act 2009, s 36.

115 Neville Cox, 'Blasphemy, Holocaust Denial, and the Control of Profoundly Unacceptable Speech' (2014) 62 Am J Comp L 739, 744.

116 Ryan Nugent, "We made blasphemy law "almost impossible to prosecute" - former minister says about Stephen Fry garda investigation' The Irish Independent (8 May 2017) <www.independent.ie/irish-news/wemade-blasphemy-law-almost-impossible-to-prosecute-former-minister-says-about-stephen-fry-gardainvestigation-35690071.html> accessed 20 March 2018.

117 According to a 2017 report by the United States Commission on International Religious Freedom, of all 71 countries with blasphemy laws on the books, Ireland had the least restrictive legislation (evaluated against international human rights law standards). See Joelle Fiss and Jocelyn Getgen Kestenbaum, 'Respecting Rights? $\begin{array}{llccl}\text { Measuring the } & \text { World's } & \text { Blasphemy } & \text { Laws' } & \text { (2017) } \\ \text { <www.uscirf.gov/sites/default/files/Blasphemy\%20Laws\%20Report.pdf> accessed 20 March 2018. }\end{array}$

<www.uscirf.gov/sites/default/files/Blasphemy\%20Laws\%20Report.pdf> accessed 20 March 2018 .
${ }^{118}$ Recent events lend further credence to this proposition. When Stephen Fry was asked on television what he would say to god if given the chance, he responded 'Why should I respect a mean-minded, stupid god who creates a world so full of injustice and pain?' and stated 'the god who created this universe, if it was created by God, is quite clearly a maniac, an utter maniac, totally selfish'. A single member of the Irish public filed a complaint with the police, because he believed Fry's remarks constituted blasphemy under the Defamation Act 2009 (the complainant himself did not, however, feel offended by the remarks). For the next 18 months, the Irish police apparently sat on the complaint. The police eventually did look into the matter, but halted the investigation when they could not find anyone who felt outraged over Fry's remarks. For all intents and purposes, then, blasphemy was the object of legal tolerance in Ireland. See Pádraig Collins, 'Stephen Fry investigated by Irish police for alleged blasphemy' The Guardian (7 May 2017) <www.theguardian.com/culture/2017/may/07/stephen-fry-investigated-by-irish-police-for-alleged-blasphemy> accessed 20 March 2018; Henry McDonald, 'Irish police halt investigation of Stephen Fry for blasphemy' The Guardian (10 May 2017) <www.theguardian.com/culture/2017/may/09/irish-police-halt-prosecution-of-stephenfry-for-blasphemy> accessed 20 March 2018.

${ }^{119}$ In response to the clear results of the constitutional referendum $-65 \%$ of those who voted, voted to remove the crime of blasphemy from the Irish Constitution - the Minister for Justice of Ireland stated: 'We have again sent a message to the world, a strong message that laws against blasphemy do not reflect Irish values and that we do not believe such laws should exist.' See McGarry (n 73).
} 
Whether, and when, religious persons should be exempt from complying with general laws is a deeply contested question, especially when the general law at issue confers rights on others in relation to morally divisive issues like abortion or same-sex marriage. Lawmakers may outright reject exemptions for individuals who refuse to facilitate abortions or same-sex marriages. ${ }^{120}$ In those circumstances, the law refuses to tolerate religious claims of conscience. But when the law does grant exemptions, is it 'merely' tolerating objectionable beliefs? Or do legal exemptions signal acceptance of - or indifference towards - religious conscience? I will suggest that, although legal responses to conscientious objections vary, at least some take the form of pragmatic legal tolerance.

When states introduce same-sex marriage, they are likely to face the divisive question of how to respond to registrars who object, for religious reasons, to registering same-sex marriages. Some states have opted for legal exemptions. South Africa and the Netherlands are probably the most significant examples. The Dutch example will be discussed first, as it is a clear instance of legal tolerance, whereas the South African case is more difficult to classify.

The Dutch legal history of civil servants who refuse to register same-sex marriages is marked by a transition from pragmatic legal tolerance to principled prohibition. In the immediate aftermath of the introduction of same-sex marriage in $2001,{ }^{121}$ Dutch civil servants who refused to register same-sex marriages benefitted from pragmatic legal tolerance. During the parliamentary debate on the same-sex marriage bill, the Dutch government suggested that municipalities should adopt a practical solution to religious claims of conscience. This

\footnotetext{
${ }^{120}$ Lawmakers in Finland and Sweden, for instance, have refused to include conscience clauses for doctors in their abortion legislation. See Christian Fiala and others, 'Yes We Can! Successful Examples of Disallowing "conscientious Objection" in Reproductive Health Care' (2016) 21 Eur J Contraception \& Reproductive Health Care 201, 201. Similarly, judges in the United Kingdom and the United States have rejected exemptions from equality legislation for civil servants, hotel owners, wedding photographers and others who refuse to facilitate same-sex partnerships and marriages. See, among others, Ladele v London Borough of Islington [2009] EWCA Civ 1357, [2010] IRLR 211; Bull v Hall [2013] UKSC 73, [2013] 1 WLR 3741; Elane Photography v Willock 309 P.3d 53 (NM 2013).

121 Wet van 21 december 2000 tot wijziging van Boek 1 van het Burgerlijk Wetboek in verband met de openstelling van het huwelijk voor personen van hetzelfde geslacht (entered into force on 1 April 2001).
} 
practical solution took the form of allowing colleagues to take over duties of civil servants who objected to registering same-sex marriages. ${ }^{122}$

Initially, the pragmatic solution was widely endorsed, including by the Dutch Equality Commission. ${ }^{123}$ In the decade that followed, however, the legal ${ }^{124}$ and political ${ }^{125}$ debate gradually shifted from pragmatic tolerance towards principled prohibition. This signals a (possible) instability at the heart of legal tolerance, whereby tolerance acts as an interim or transitional response to contested issues. I discuss this (potential) implication of legal tolerance below, in section 4 .

The Dutch parliament eventually responded to legal and political developments by enacting legislation, in 2014, to bar persons who would violate equality legislation from eligibility for the position of civil servant. ${ }^{126}$ The 2014 Act thus substituted a principled legal prohibition for the previous policy of pragmatic legal tolerance. 'Giving space to claims of conscience generally fits in the Dutch tradition of tolerance', parliament acknowledged, 'but unfortunately there are also developments in the Netherlands that oppose that tradition (...) The problem is that religions are not always equally tolerant'. ${ }^{127}$ ' $[\mathrm{I}] \mathrm{n}$ a climate of intolerance', parliament continued, 'what helps is not the mere searching for pragmatic

\footnotetext{
${ }^{122}$ See Equality Commission (the Netherlands), Opinion 2002-25 [2.3] (unreported).

123 ibid [5.8]. See also Equality Commission (the Netherlands), Opinion 2002-26 (unreported).

${ }^{124}$ Initially, the Dutch Equality Commission supported the pragmatic solution. See Equality Commission (the Netherlands), Opinion 2002-25; Equality Commission (the Netherlands), Opinion 2002-26. A few years later, however, the Equality Commission changed course. It 'discovered' that it had simply accepted the pragmatic solution in previous opinions, without truly engaging arguments of principle. Convinced by the strength of those principled argument, the Commission now held that civil servants could not refuse to comply with the law on same-sex marriage, for in doing so they violated the equality principle. See Equality Commission (the Netherlands), Opinion 2008-40 (unreported), particularly at [3.10] and [3.27].

${ }^{125}$ As subsequent governments repeated their commitment to the pragmatic solution, members of parliament started insisting on stringent limits to the right to conscientious objection of civil servants.

${ }^{126}$ Wet van 4 juli 2014 tot wijziging van het Burgerlijk Wetboek en de Algemene wet gelijke behandeling met betrekking tot ambtenaren van de burgerlijke stand die onderscheid maken als bedoeld in de Algemene wet gelijke behandeling, Article 1.2.

${ }^{127}$ Explanatory report to ibid 5.
} 
solutions to the consequences of intolerance, but consistently upholding the prohibition of discrimination'. ${ }^{128}$

The Dutch example is thus an instance in which pragmatic legal tolerance was eventually replaced by principled prohibition. The South African response to the same issue, conversely, is more difficult to classify. Same-sex marriage was introduced in South African law through the Civil Union Act 2006, as a direct consequence of a Constitutional Court judgment in which lack of legal recognition of same-sex relationships was found to violate the Constitution's equality provision. ${ }^{129}$ Although conscientious objections by civil servants were not at issue in the constitutional case, the Constitutional Court indicated in obiter dicta that such objections could be dealt with through reasonable accommodation. ${ }^{130}$ As Elsje Bonthuys notes, 'Parliament eagerly seized upon the idea' to include a conscience clause in section 6 of the Civil Union Act 2006. ${ }^{131}$

In the absence of clear legislative statements on the rationale for the conscience clause, it is difficult to establish whether it aims to respect religious conscience as a positive good or merely tolerate it as an inevitable response to same-sex marriage. The South African parliamentary debate is largely silent on the reasons for inclusion of the conscience clause, although a minor party did allege that the African National Congress included the clause for strategic reasons, 'in order to appease both sides' ${ }^{132}$ From that perspective, the conscience

\footnotetext{
128 ibid 6.

${ }^{129}$ Minister of Home Affairs v Fourie 2006 (1) SA 524 (CC).

130 ibid [159].

${ }^{131}$ Elsje Bonthuys, 'Irrational Accommodation: Conscience, Religion and Same-Sex Marriages in South Africa Note' (2008) 125 S Afr Law J 473, 474. Section 6 of the Civil Union Act 2006 reads: 'a marriage officer (...) may in writing inform the Minister that he or she objects on the grounds of conscience, religion and belief to solemnising a civil union between persons of the same sex, whereupon that marriage officer shall not be compelled to solemnise such civil unions'.

${ }^{132}$ LW Greyling, speaking for the Independent Democrats (ID) during the plenary reading of the Civil Union Bill on 14 November 2006: 'What has shocked the ID, however, has been the attitude of the ANC on this issue. Instead of showing true leadership, they chose to compromise on constitutional principles in an effort to appease both sides.' See <https://biblio.wiki/wiki/National_Assembly_debate_on_the_Civil_Union_Bill> accessed 20 March 2018.
} 
clause could have served the pragmatic goal of ensuring sufficient buy-in for the morally divisive introduction of same-sex unions in South African law. ${ }^{133}$

Conscience clauses for doctors ${ }^{134}$ in abortion legislation are analogous to exemptions for marriage officers in South Africa, in the sense that they can either signal respect for or indicate mere tolerance of conscientious objections. The law's response to doctors who refuse to perform abortions moreover interacts with its approach to abortion itself. Let me clarify the last point. Respect for doctors' conscientious objections may well be a marker for mere tolerance of abortion. If the law does no more than tolerate abortion, we can expect to see non-coercive measures to curb abortions even after women have gained a (limited) legal right thereto. Conscience clauses may act as such non-coercive measures to restrict practical access to abortion, especially when disapproval of abortion among doctors is widespread.

Conversely, when states respect a woman's decision to have an abortion, they are likely to disapprove of doctors who impose obstacles on abortion. Such states may still grant doctors legal exemptions, but only as a limited exception to the general rule that grants women uninhibited access to abortion services. In this case, exemptions are a marker of 'mere' legal tolerance. If objections would become so widespread as to effectively hinder women's access to abortion, states would presumably retract policies of legal tolerance and force doctors to perform abortions.

These two contrasting responses to conscientious objection to abortion - one a sign of respect, the other a mark of legal tolerance - can be seen at work in Italy and Norway. In Italy, abortion itself arguably remains the object of 'mere' legal tolerance. Although Italian

\footnotetext{
${ }^{133}$ Other factors lend some credence to this hypothesis. For instance, as the Constitutional Court noted in Fourie (n 129), same-sex marriage could have been introduced through a simple textual amendment of the Marriage Act 1961. Instead, the South African Parliament introduced it through a separate piece of legislation, which avoided the term 'marriage' in its title.

${ }^{134}$ For ease of writing and reading, I only reference doctors in the text. But conscience clauses may of course extend to other medical and hospital staff.
} 
women have a legal right to abortion, its exercise is subject to restrictive conditions. ${ }^{135} \mathrm{~A}$ whole range of practical obstacles further limits access to lawful abortions, to the point where gaining access can become impossible. Only gynaecologists can perform abortions in Italy. But in many regions of the country, including Lazio (the region of Rome), more than $80 \%$ of gynaecologists refuse to perform abortions for religious reasons. ${ }^{136}$ Access is further inhibited by the fact that over $85 \%$ of all abortions in Italy are surgical. ${ }^{137}$ Because surgical abortions require more direct ('hands-on') medical intervention in the termination of pregnancies, their prevalence strengthens the case for widespread exemptions. ${ }^{138}$

When, as in Italy, a whole range of circumstances makes conscientious objection the rule and access to abortion an exception, ${ }^{139}$ it is difficult to characterize the situation as one of legal tolerance of conscientious objections. It seems, rather, that in Italy respect for doctors' conscience goes hand in hand with mere tolerance of abortion itself.

In countries like Norway, conversely, abortion seems to be accepted rather than tolerated. Not only is Norway's abortion legislation more liberal, ${ }^{140}$ but - more importantly Norwegian women also face fewer practical obstacles in accessing abortion than Italian women. In Norway, more than $85 \%$ of all abortions are medical and doctors with conscientious objections appear to constitute a very small minority. ${ }^{141}$ Under those

\footnotetext{
${ }^{135}$ Legge n. 194 (1978) legalizes abortion during the first 90 days of pregnancy for economic, family, health, or personal reasons, but also provides that women must first undergo an exam and 'options counselling' to gain access to the procedure. Afterwards, they must still wait seven days to have the procedure, unless termination is urgent. See Wendy Chavkin and others, 'Regulation of Conscientious Objection to Abortion: An International Comparative Multiple-Case Study' (2017) 19 Health Hum Rights 55, 59.

136 ibid 59-60.

137 ibid 59.

${ }^{138}$ Things might be changing, however. The region of Lazio, for instance, recently became the first in Italy to promote medical abortions to 'make access to Law 194 [which regulates abortion] the least onerous possible for women' (own translation). See Anna Rita Cillis and Maria Novella de Luca, 'La pillola dell'aborto anche in consultorio, rivoluzione nel Lazio' La Repubblica (5 April 2017) <www.repubblica.it/salute/2017/04/05/news/la_pillola_dell_aborto_anche_in_consultorio_rivoluzione_nel_lazio $-162223561 />$ accessed 20 March 2018.

${ }^{139}$ Chavkin (n 135) 60.

${ }^{140}$ Act No. 50 (1975) allows abortion on request before the $12^{\text {th }}$ week of pregnancy and in limited circumstances until week 18. See Chavkin (n 135) 60.

141 ibid 61.
} 
circumstances, conscientious objection is arguably the tolerated exception to a rule that enables uninhibited access to abortion (insofar as the law permits abortion, of course). The key question is, what leads states like Norway to tolerate conscientious objection to abortion, rather than prohibit it?

At least some of the reasons are deontological. Above, in section 2, I rejected deontological reasons insofar as they draw on the value of personal autonomy, since reliance thereon risks intensifying societal division over abortion rather than alleviating it. But other deontological reasons are available. From the religious doctor's perspective, coercing her to act against her conscience entails forcing her to kill what she considers to be a human being. By including conscience clauses in abortion legislation, Norway arguably recognizes the difficult moral position in which doctors with religious objections find themselves. Importantly, reliance on this deontological reason can be less divisive than deferral to doctors' personal autonomy, because the reason could - in principle - also be shared by proponents of abortion. Indeed, doctors' religious objections can be expressed in terms of the value of life. Legal tolerance of conscientious objections to abortion can then be grounded in that shared reason, rather than drawing its validity from a contested reason (eg deference to personal autonomy).

But, as intimated in section 2, conscientious objection to abortion can also be tolerated for pragmatic reasons. In the United Kingdom, for instance, inclusion of a conscience clause in the Abortion Act 1967 appears to have been a prerequisite for the successful enactment of abortion legislation. ${ }^{142}$ The conscience clause was part of a legal package intended to enhance the safety of abortion procedures. The Abortion Act 1967 aimed, at least in part, to move abortion from the unsafe corners of 'back-street' practitioners into regulated environments, in

\footnotetext{
${ }^{142}$ Greater Glasgow Health Board v Doogan [2014] UKSC 68, [2015] 2 WLR 126 [27] ('The conscience clause [of the Abortion Act 1967] was the quid pro quo for a law designed to enable the health care profession to offer a lawful, safe and accessible service to women').
} 
which the safety of the procedure could be ensured. ${ }^{143}$ Conscience clauses in abortion legislation arguably continue to fulfil an analogous pragmatic function, especially in relation to surgical abortions. Doctors with religious objections to abortion would presumably find it extremely difficult to complete abortion procedures if coerced to do so. From a pragmatic perspective, then, tolerating claims of conscience, rather than forcing doctors to perform abortions, serves to ensure the safety of the procedure.

\section{Implications of Legal Tolerance}

With a broad range of practical examples in hand, we can now revisit the core case for pragmatic legal tolerance and draw out some of its implications. At the start of this article, I formulated a case for pragmatic legal tolerance against two counterarguments from philosophy: (i) the political liberal argument that the state's duty of neutrality precludes it from engaging in legal tolerance; and (ii) the moral argument for a move beyond the 'secondbest' attitude of tolerance towards respect. Although both arguments restrict - or even eliminate - the theoretical space for legal tolerance in constitutional democracies, legal practice shows that many constitutional democracies continue to pursue policies of legal tolerance in relation to contested moral issues. The discussed examples thus buttress the conceptual claim that legal tolerance plays an important role in law.

At the start of this article, however, I did more than set out a case for legal tolerance. I formulated the more specific case for pragmatic legal tolerance. In doing so, I hypothesized that legal tolerance is most likely to reduce societal division over contested issues when it is supported by pragmatic reasons. By basing legal tolerance on pragmatic grounds, I argued, lawmakers can effectively sidestep contested value judgments, thereby minimizing the risk

\footnotetext{
143 ibid [27] ('the policy of the 1967 Act [was] to ensure that abortion was carried out with all proper skill and in hygienic conditions [whereas before] many women [sought] the services of "back-street" abortionists, which were often unsafe').
} 
that their adopted legal policies will increase polarization in society. Some of the discussed examples illustrate this point. Legal tolerance of prostitution in the Netherlands, for instance, serves (or served, until 2000) the pragmatic aim of enabling state control of a contested practice, in a bid to increase sex workers' safety and hygiene. It is not based on the inherent goodness or 'necessary evil' of sex work. Similarly, constitutional protection of hate speech in the United States is not founded on a divisive argument that hateful viewpoints are inherently valuable. Instead, American legal tolerance of hate speech is (best) supported by pragmatic arguments about the risk of abuse of government power. Persistent controversy over hate speech in the US is arguably connected to the state's failure to adequately ground legal tolerance exclusively in the pragmatic reason of the fortress model (eg by insisting instead on the importance of the free discovery of truth).

Some of the other discussed examples, however, indicate that there are limits to the pragmatic case for legal tolerance. Consider, for instance, legal tolerance of conscientious objection to same-sex marriage in the Netherlands and South Africa. Such legal tolerance is or could at least be - based on pragmatic grounds, including the practical possibility of avoiding a clash of competing worldviews or the need to garner sufficient support for samesex marriage. Legal tolerance of conscientious objection need thus not equate to endorsement of a religious perspective on marriage. In practice, however, legal tolerance of conscientious objection to same-sex marriage has been extremely divisive in both South Africa and the Netherlands. ${ }^{144}$ In South Africa, this could be related to ambivalence in the rationale for the conscience clause in the Civil Union Act. It is not clear whether that clause 'merely' serves pragmatic purposes or instead maintains a moralizing tradition that endorses religious

\footnotetext{
${ }^{144}$ In South Africa, close to $40 \%$ of all marriage officers in South Africa are now exempt from their legal duty to solemnize same-sex unions, prompting calls for amendment of the Civil Union Act 2006 to ensure greater and more reliable access to same-sex marriage. See Carl Collison, 'Home affairs minister rejects call to amend discriminatory same-sex law' Mail \& Guardian (19 July 2017) <http://mg.co.za/article/2017-07-18-homeaffairs-minister-rejects-call-to-amend-discriminatory-same-sex-law> accessed 20 March 2018. See also Helen Kruuse, 'Conscientious Objection to Performing Same-Sex Marriage in South Africa' (2014) 28 Int J Law Policy Family 150.
} 
perspectives on marriage. But even when legal exemptions for conscientious objectors to same-sex marriage clearly serve only pragmatic ends, as in the Netherlands prior to 2014, they have proven unsustainable. The Dutch experience with conscientious objection to samesex marriage suggests, in other words, that pragmatic legal tolerance can be unstable.

Instability of pragmatic legal tolerance ought not come as a surprise. Given its schizophrenic nature, tolerance may well be inherently unstable. Bernard Williams conceived of tolerance along those lines. Williams thought of tolerance as 'an interim value, serving a period between a past when no one had heard of it and a future in which no one will need it'. ${ }^{145}$ Some of the examples discussed in this article confirm that legal tolerance can be a transitional measure between a past of prohibition and a future of acceptance. ${ }^{146}$ Legal responses to blasphemy are a case in point. In most constitutional democracies, the law's attitude towards blasphemy has evolved from prohibition over tolerance to acceptance. Recent constitutional events in Ireland, described above, confirm as much. The transitional process is also evident in legal responses to prostitution in the Netherlands, where enforcement of the criminal prohibition of prostitution was gradually replaced by policies of legal tolerance, which were in turn substituted by legalization. If sex work is not already fully accepted in the Netherlands, ${ }^{147}$ rather than tolerated, it likely will be soon.

Yet instability of legal tolerance need not be a precursor to acceptance. Legal tolerance can also collapse into the other 'extreme': prohibition. ${ }^{148}$ This occurred in Sweden in 1998, when legal tolerance of prostitution was replaced by a prohibitionist approach. A similar scenario unfolded in the Netherlands in relation to conscientious objection to same-sex marriage. In other circumstances, still, pragmatic legal tolerance has proven remarkably

\footnotetext{
${ }^{145}$ Bernard Williams, as cited in Horton (n 3) 294.

146 See also Buruma (n 24) 88 (making an analogous point about euthanasia in the Netherlands).

147 Outshoorn (n 41) 165 ('Prostitution is no longer a controversial moral issue, but is now defined as sex work').

148 This scenario was not envisioned by Williams, for whom tolerance was an interim value on the path to acceptance.
} 
resilient, casting doubt on any idea that tolerance is inherently unstable. The most prominent example is legal tolerance of hate speech in the United States, which is highly unlikely to evolve into acceptance or collapse into prohibition anytime soon. The same goes for legal tolerance of doctors' conscientious objection to abortion in states like Norway or the United Kingdom. It seems all but inevitable that disapproval of doctors' refusal to perform abortions in those countries will intensify rather than fade away. Yet there are no indications that either country will retract its conscience clause from abortion legislation in the foreseeable future.

What, then, might explain the relative (in)stability of pragmatic legal tolerance? Part of the explanation, I venture, resides in the declining influence of religious perspectives on morality. Moralistic reasons of the Augustinian variety, in particular, have little traction in contemporary constitutional democracies. ${ }^{149}$ Instead, legal interventions are generally driven by harm analysis. Pragmatic legal tolerance is, in that respect, subject to evolving knowledge, assumptions and perceptions about harms caused by divisive beliefs, opinions and practices. As long as our knowledge, assumptions and perceptions remain stable, policies of legal tolerance are likely to remain stable as well. This would explain the relative stability of legal tolerance of hate speech in the United States and of conscientious objection to abortion in Norway and the United Kingdom.

When scientific knowledge or majority perceptions about harm change, however, legal tolerance becomes unstable. If mounting scientific evidence and evolving assumptions point towards an absence of harm - to self and/or others - states are likely to transition away from legal tolerance towards acceptance. This is what happened to blasphemy in most constitutional democracies. It is also what occurred to sex work in the Netherlands, ${ }^{150}$ and

\footnotetext{
${ }^{149}$ See also Cox (n 107) 743 ('the concept of a law existing to protect a particular belief system at a cost to the right to free speech is, of course, anathema in 2014').

${ }^{150}$ In 1997, for instance, $74 \%$ of the Dutch population regarded prostitution as an acceptable job and $73 \%$ was in favour of legalizing brothels. See Brants (n 32) 630.
} 
marijuana consumption in Canada. But scientific evidence and perceptions on harm can also go the other way, causing legal tolerance to collapse into prohibitionist policies. This occurred to prostitution in Sweden in $1998,{ }^{151}$ and to conscientious objection to same-sex marriage in the Netherlands in 2014. In the Netherlands, the move from tolerance towards prohibition was spurred by deontological reasons for prohibition 'trumping' pragmatic reasons for legal tolerance. In Sweden, conversely, the shift from tolerance to prohibition was largely driven by scepticism about the effectiveness of pragmatic legal tolerance. ${ }^{152}$ I will say a bit more on this in the conclusion.

The second implication of pragmatic legal tolerance is a concomitant of its instrumental value. The message sent by policies of legal tolerance is that lawmakers do not accept, but merely tolerate certain contested practices and opinions (in some circumstances). This presupposes, however, that lawmakers somehow communicate their stance of tolerance, including the disapproval it entails. If they do not, legal tolerance is likely to be mistaken for indifference or even acceptance. ${ }^{153}$ The pragmatic case for legal tolerance thus depends on lawmakers utilizing their expressive or communicative power.

In that sense, the case for pragmatic legal tolerance aligns with Corey Brettschneider's theory of 'value democracy'. ${ }^{154}$ Brettschneider argues that state authorities should refrain from using their coercive power to restrict discriminatory practices like hate speech, but ought to simultaneously engage their expressive power to criticize hateful viewpoints. ${ }^{155}$ In doing so, Brettschneider posits, states can avoid complicity in hate speech by clarifying that they do

\footnotetext{
${ }^{151}$ And in the United States during the Progressive Era. See text to n 33.

152 See Scoular (n 35).

153 Buruma (n 24) 109.

${ }^{154}$ Corey Lang Brettschneider, When the State Speaks, What Should It Say? How Democracies Can Protect Expression and Promote Equality (Princeton University Press 2012).

155 Ibid. For a similar account, see Tarunabh Khaitan, A Theory of Discrimination Law (OUP 2015) 111-12.
} 
not condone it: '[t]he state's protection of [hateful] viewpoints ... is not equivalent to the state's indifference to them'. ${ }^{156}$

Lawmakers communicate the disapproval implicit in legal tolerance in a variety of ways. The most straightforward way is inherent in the category of legal tolerance under which states de facto permit practices that are de jure illegal. Here, the (unenforced) criminal law expresses disapproval towards the tolerated practice. Consider, for instance, the sale and consumption of marijuana in the Netherlands. The Netherlands has opted for legal tolerance by deliberately refraining from enforcing the criminal law. But it has not amended the criminal law. Instead, it has kept it in place as a persistent reminder of its (unenforced) disapproval of the sale and consumption of marijuana.

In relation to the other form of legal tolerance, however, under which lawmakers disapprove of practices that are entirely legal, communication of disapproval becomes vital. If, in these cases, lawmakers do not communicate their disapproval, citizens are likely to mistake their policies for indifference or acceptance, rather than tolerance. This would render legal tolerance redundant or superfluous. Fortunately, Vincent Blasi tells us, '[t]he distinction between tolerance and agreement is ... easily explained and easily understood [so that] it is a distinction that the rhetoric of law can effectively teach'. ${ }^{157}$ Throughout this article, we have seen how the rhetoric of law can be deployed to communicate the disapproval inherent in legal tolerance. Consider, for instance, hate speech in the United States. When neo-Nazis intended to march in Skokie, a Court of Appeals upheld their First Amendment rights, but also expressed 'repugnance' at their 'generally unacceptable' doctrines. ${ }^{158}$ Court have even explained that hate speech is tolerated for pragmatic reasons, because the alternative of

\footnotetext{
156 Brettschneider (n 154) 46.

157 Blasi (n 93) 409.

${ }^{158}$ Collin (n 84) 1200 and 1203 ('We would hopefully surprise no one by confessing personal views that NSPA's beliefs and goals are repugnant to the core values held generally by residents of this country, and, indeed, to much of what we cherish in civilization.').
} 
entrusting the government with the power to determine what constitutes 'good' and 'bad' speech would be more harmful. The Supreme Court of the United States has for instance stated that 'in public debate [we] must tolerate insulting, and even outrageous, speech in order to provide adequate "breathing space" to the freedoms protected by the First Amendment'. ${ }^{159}$

In the hate speech example, disapproval is communicated directly, in that it takes the form of state speech (in casu uttered by courts). But the disapproval inherent in legal tolerance need not be communicated through speech. It can also be expressed through nonverbal communicative action. Consider, for instance, legal tolerance of tobacco use. Lawmakers advertise their disapproval of smoking in a variety of ways. They use speech by directing manufacturers to display dissuasive labels on tobacco products, often accompanied by graphic images, that point towards self-harm ('Smoking causes fatal lung cancer') or thirdparty harm ('Protect children: don't make them breathe your smoke'). ${ }^{160}$ But they also deploy non-speech measures. Lawmakers restrict the public spaces in which smoking is allowed, ban commercial advertising for tobacco products and increase taxes on their sale. They thereby signal their disapproval of smoking, indicating that it is now 'merely' the object of legal tolerance. Such use of state communicative power, regardless of the precise form it takes, is a prerequisite to making pragmatic legal tolerance work. As we are about to see in the conclusion, however, there are limits to the pragmatic case for legal tolerance.

\section{Conclusion}

In this article, I have aimed to lay the conceptual groundwork for a pragmatic case for legal tolerance. I have done so by substantiating two claims with reference to legal practice. First, the conceptual claim that state tolerance continues to play a central role in law, despite

\footnotetext{
${ }^{159}$ Snyder (n 79) 12, citing Boos v Barry.

${ }^{160}$ In the European Union, these labels are mandatory under EU law and uniform across all EU states. The examples in the text are taken from the labels for the United Kingdom (Brexit may of course put an end to these labels in the UK, at least in their current form). See European Commission, 'Health Warnings' <https://ec.europa.eu/health/tobacco/products/health-warnings_en> accessed 20 March 2018.
} 
philosophical arguments that negate the salience of state tolerance in liberal democracies. Second, the hypothesis that legal tolerance is (best) grounded on pragmatic reasons, instead of grand ideological claims.

In substantiating both claims, I have made an initial case for pragmatic legal tolerance. I have, however, in no sense intended to make a conclusive case for pragmatic legal tolerance. Nothing I have written should be read to imply that legal tolerance is necessarily the best - or even an appropriate - state response to divisive beliefs, opinions and practices. Depending on the circumstances, acceptance, respect, indifference or prohibition may well be more suitable responses. I have merely argued that, philosophical arguments to the contrary, actual practice shows that (a) certain beliefs, opinions and practices are the object of legal tolerance and (b) such legal tolerance is often - and best - supported by pragmatic reasons.

There are, however, limits to what pragmatic legal tolerance can achieve. These limits are of two kinds: practical limits to the effectiveness of pragmatic legal tolerance (Can pragmatic tolerance succeed on its own pragmatic terms?) and normative limits to its acceptability (Is legal tolerance an acceptable response to difference?). The normative question asks us to choose between neutrality, tolerance, respect and prohibition (and the attending attitudes of indifference, disapproval overcome, acceptance and disapproval followed through). This is, in the first place, a philosophical question. Although its answer is crucial for our conception of liberal democracy - and for how we think the law should respond to difference - I do not engage it here. ${ }^{161}$ In keeping with the pragmatic aims of this article, I only explore the practical question in these concluding remarks.

The practical question invites us to evaluate the effectiveness of pragmatic legal tolerance. Throughout this article, I have highlighted a few cases in which lawmakers have

\footnotetext{
${ }^{161}$ For discussion in the specific context of conscientious objection, see Stijn Smet, 'Conscientious Objection through the Contrasting Lenses of Tolerance and Respect' (unpublished manuscript; on file with the author) [note for proofs: update once/if accepted for publication].
} 
opted against legal tolerance, driven by scepticism of its promise of responding effectively to divisive issues. Scepticism of pragmatic tolerance for instance drives the US federal government's zero tolerance policy towards all drugs, including marijuana, and it has spurred Sweden to transition away from legal tolerance of prostitution to prohibitionist laws.

Although these sceptical arguments are open to empirical testing, at least some are based on assumptions rather than empirical evidence. This seems, for instance, to be the case for the zero tolerance policy on marijuana of the US federal government. Crucially, however, the exact same thing can be said of some of the pragmatic arguments for legal tolerance. For instance, the pragmatic argument for legal tolerance of hate speech in the United States - the fortress model - is arguably based on assumptions, not evidence, about the consequences of allowing government regulation of the content of speech.

Yet, to be sustainable lawmakers' choices both for and against pragmatic legal tolerance need to be supported by empirical evidence, not assumptions. It has not been my aim in this article to provide the necessary empirical data to buttress this claim. That is, I have not set out to prove or disprove the effectiveness of pragmatic legal tolerance. Instead, my aim has been to supply the necessary conceptual groundwork for a pragmatic case for legal tolerance. With that conceptual foundation firmly in place, (more) empirical research is needed to investigate the extent to which the pragmatic case for legal tolerance can meet its own pragmatic ambitions. Similarly, (more) legal-philosophical work is needed to determine when - or if - legal tolerance is an acceptable response to contested moral issues. In the meantime, the arguments supplied in this article suggest that pragmatic legal tolerance can be an effective tool for lawmakers to respond to divisive moral issues. 